\title{
AKTIVITAS ANTIJAMUR EKSTRAK DAUN KETEPENG CINA (Cassia alata L.)
}

\author{
Oktaviany Triana*, Fajar Prasetya, Hadi Kuncoro, Laode Rijai \\ Laboratorium Penelitian dan Pengembangan FARMAKA TROPIS, Fakultas Farmasi, \\ Universitas Mulawarman, Samarinda, Kalimantan Timur \\ Corresponding author email : viviokta@gmail.com
}

\begin{abstract}
Research of potential antifungal Candle bush's leaf extract (Cassia alata L.) have been done. The research done by the method of extraction by maceration using methanol solvent and continued by fraksinasi. Extract get a tes to know potential the antifungal with diffusion method and used a paper disc in different consentration. Analysis of the test is done by measuring the diameter of the zones of fungal growth inhibitory extract. The result of antifungal activity test shows that Candle bush's leaf has antifungal activity against M. furfur
\end{abstract}

Key Word : Antifungal, Malassezia furfur, Cassia alata L.

\section{ABSTRAK}

Telah dilakukan penelitian yang berjudul Aktivitas Antijamur Ekstrak Daun Ketepeng Cina (C. alata L.). Penelitian dilakukan dengan metode ekstraksi secara maserasi dengan menggunakan pelarut metanol dan dilanjutkan dengan fraksinasi. Ekstrak diuji aktivitas antijamurnya dengan menggunakan metode difusi agar menggunakan paper disk dengan tingkat konsentrasi yang berbeda. Analisis uji ini dilakukan dengan mengukur diameter zona hambatan ekstrak terhadap pertumbuhan jamur. Hasil uji aktivitas antijamur menunjukkan bahwa ekstrak daun ketepeng cina memiliki aktivitas antijamur terhadap jamur $M$. furfur.

Kata Kunci : Antijamur, Malassezia furfur, Ketepeng Cina.

$$
\text { Submitted on: } 7 \text { Januari } 2017 \quad \text { Accepted on: } 8 \text { juli } 2017
$$

DOI: https://doi.org/10.25026/jsk.v1i6.67

\section{PENDAHULUAN}

Penyakit infeksi merupakan salah satu masalah dalam bidang kesehatan yang terus berkembang. Penyakit ini masih merupakan penyakit utama di negara-negara berkembang termasuk Indonesia (Nelwan, 2006). Penyakit ini dapat ditularkan dari satu orang ke orang lain atau dari hewan ke manusia. Berbagai mikroorganisme yang dapat menyebabkan infeksi antara lain bakteri, virus, jamur, dan parasit (Jawetz et al., 2001).

Infeksi dapat disebabkan oleh mikroorganisme seperti jamur. Jamur sebenarnya merupakan organisme yang tidak begitu patogen terhadap manusia, tetapi akan menimbulkan penyakit bila keadaan memungkinkan untuk menginfeksi manusia. Beberapa jenis jamur bahkan normal berada dalam tubuh manusia. Terjadinya infeksi ini dipermudah dengan adanya faktor predisposisi dan faktor pencetus contohnya seperti banyak berkeringat dan lembab (Bahry,1995).

Antijamur adalah obat yang paling banyak diresepkan untuk pengobatan infeksi. Penggunaan antijamur secara tidak rasional dapat menimbulkan efek samping dan resisten (Priyanto, 2009). Pemanfaatan bahan alam dalam upaya penemuan antijamur yang baru dan lebih efektif melawan infeksi perlu dikembangkan. 
Indonesia sudah terkenal merupakan negara yang kaya bahan alam. Salah satu bahan alam yang memiliki potensi untuk diteliti adalah ketepeng cina ( $C$. alata L.). Selama ini ketepeng cina banyak dimanfaatkan secara tradisional, antara lain adalah sebagai antiparasit, laksan, kurap, kudis, panu, eksem, malaria, sembelit, radang kulit bertukak, sifilis, herpes, influenza dan bronchitis. Daun ketepeng cina memiliki kandungan penting seperti alkaloid, saponin, tannin, steroid, antrakuinon, flavonoid dan karbohidrat. Flavonoid pada tanaman herbal memiliki efek antiinflamasi, antialergi, antibakteri terhadap Aspergillus fumigatus and Microsporum canis (Somcit et al., 2002; Pongphaicit et al., 2004), antioksidan, dan efektif untuk beberapa golongan jamur (Rahman, 2010).

Berdasarkan pertimbangan tersebut maka pada penelitian ini dilakukan uji aktivitas antijamur ekstrak daun ketepeng cina (C.alata L.) terhadap jamur uji $M$. furfur.

\section{METODE PENELITIAN}

\section{Bahan Penelitian}

Bahan yang diteliti adalah daun ketepeng cina (C. alata L.). Biakan jamur $M$. furfur, air suling, metanol, paper disk, medium PDA, pelarut n-heksana, etil asetat, dan n-butanol.

\footnotetext{
Alat

Alat yang digunakan adalah gelas kimia, gelas ukur, autoklaf, ose, spoit, keranjang, spatula, botol selai, botol vial, pinset, laminar air flow (LAF), mikrometer sekrup, pipet tetes, labu erlenmeyer, labu ukur, timbangan analitik digital, batang pengaduk, lampu spiritus, penangas air, cawan petri, rotary evaporator, inkubator, corong pisah, dan rak tabung.
}

\section{Prosedur Penelitian}

\section{Penyiapan sampel}

Sampel yang digunakan merupakan ekstrak dari daun ketepeng cina. Daun ketepeng cina segar dicuci bersih, dipotong-potong, kemudian dikeringkan dengan cara dianginanginkan. Selanjutnya daun yang telah kering dimaserasi dengan metanol. Sampel disaring sehingga didapatkan ekstrak metanol daun ketepeng cina, dipekatkan dengan menggunakan rotary evaporator pada suhu $30-40^{\circ} \mathrm{C}$. Setelah itu diuapkan dipenangas air.

\section{Fraksinasi}

Fraksinasi ini akan dibuat fraksi n-heksan, etil asetat dan n-butanol. Ekstrak metanol ditimbang sebanyak 10 gram kemudian dilarutkan dengan aquades sebanyak $100 \mathrm{~mL}$. Kemudian ditambahkan pelarut n-heksan sebanyak $100 \mathrm{~mL}$ dan dilakukan penggojokan di dalam corong pisah. Setelah beberapa menit akan terbentuk 2 lapisan. Lapisan bawah diambil untuk dilanjutkkan fraksinasi selanjutnya.

\section{Pengujian antijamur}

Dibuat pengenceran dari ekstrak dan fraksi daun ketepeng cina dengan 5 variasi konsentrasi yaitu $1 \%, 3 \%, 5 \%$, 7\%, dan 9\%. Diinokulasikan suspensi jamur uji pada medium PDA di dalam botol pengencer dan dihomogenkan. Selanjutnya medium yang telah diinokulasi tersebut dimasukkan ke dalam cawan petri steril, dibiarkan hingga memadat. Dicelupkan paperdisc ke dalam masing-masing variasi konsentrasi ekstrak, kemudian diletakkan paperdisc di atas medium sesuai dengan pola yang telah dibuat. Selanjutnya dinkubasi pada suhu $37^{\circ} \mathrm{C}$ selama 24 jam, kemudian 
diamati zona hambat yang terbentuk dan dilakukan pengukuran daerah hambatan dengan menggunakan mikrometer sekrup.

\section{HASIL DAN PEMBAHASAN}

Aktivitas antijamur adalah merupakan ukuran kemampuan ekstrak dalam membunuh maupun menghambat pertumbuhan jamur uji. Aktivitas antijamur daun ketepeng cina ditunjukkan dengan adanya zona bening atau zona keruh yaitu daerah yang bening atau keruh dimana daerah tersebut tidak ditumbuhi oleh mikroba uji atau sedikit ditumbuhi oleh mikroba uji.
Pengujian aktivitas antijamur ekstrak metanol daun ketepeng cina $(C$. alata L.) terhadap jamur $M$. Furfur, digunakan 5 variasi konsentrasi yaitu $1 \%$, $3 \%, 5 \%, 7 \%, 9 \%$. Pada variasi konsentrasi tersebut didapatkan aktivitas antijamur daun ketepeng cina yang menggunakan metode difusi agar dan hasil pengukuran rata-rata diameter zona bunuh ekstrak metanol daun ketepeng cina terhadap $M$. furfur dapat dilihat pada Tabel dan gambar 1 dan 2.

Gambar 2 menunjukkan diameter zona bunuh daun ketepeng cina terhadap pertumbuhan jamur M. furfur.

Tabel 1. Aktivitas Antijamur Malassezia furfur Ekstrak Daun Ketepeng Cina

\begin{tabular}{cccccc}
\multirow{2}{*}{ Mikroba uji } & Konsentrasi (\%) & \multicolumn{4}{c}{ Rata-Rata Diameter Zona Hambat (mm) } \\
\cline { 3 - 6 } & 1 & $\begin{array}{c}\text { Ekstrak } \\
\text { metanol }\end{array}$ & $\begin{array}{c}\text { Fraksi } \\
\text { n-heksana }\end{array}$ & $\begin{array}{c}\text { Fraksi } \\
\text { etil asetat }\end{array}$ & $\begin{array}{c}\text { Kontrol } \\
\text { Negatif }\end{array}$ \\
\hline \multirow{3}{*}{ M. furfur } & 16,96 & 8,06 & 12,33 & 0 \\
& 3 & 17,48 & 10,12 & 13,70 & 0 \\
& 5 & 20,30 & 12,92 & 16,73 & 0 \\
\hline \hline
\end{tabular}

Grafik aktivitas antijamur daun ketepeng cina terhadap jamur $M$. furfur dapat dilihat pada Gambar 1.

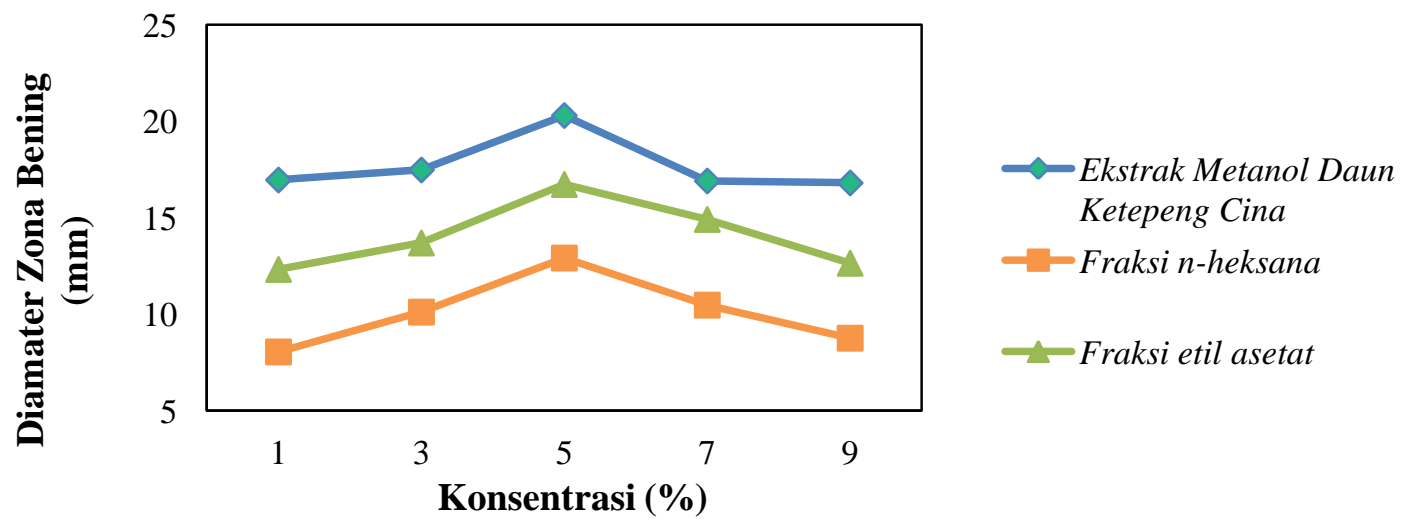

Gambar 1. Grafik zona bunuh ekstrak metanol, fraksi n-heksana, dan etil asetat daun ketepeng cina terhadap jamur Malassezia furfur 


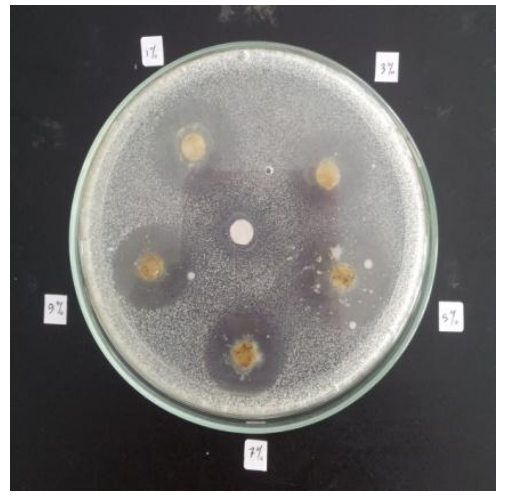

a

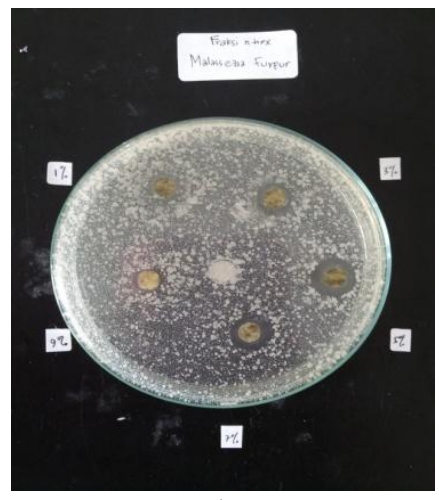

$\mathrm{b}$

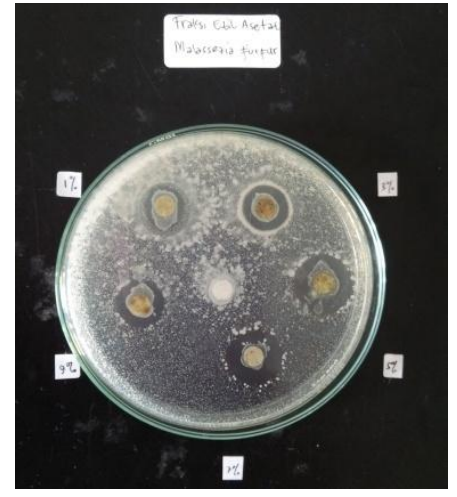

$\mathrm{C}$

Gambar 2. Diameter Zona Bunuh a). Ekstrak metanol, b). Fraksi n-heksana, c). Fraksi etil asetat

Berdasarkan hasil pengujian yang telah dilakukan diperoleh hasil pada ekstrak metanol, fraksi n-heksana dan fraksi etil asetat memiliki aktivitas antijamur ditunjukkan dengan adanya zona hambat atau zona bunuh. Sedangkan fraksi n-butanol daun ketepeng cina tidak memiliki aktivitas antijamur karena tidak terdapat adanya zona hambat atau zona bunuh yang ditunjukkan oleh fraksi tersebut. Hal ini kemungkinan karena senyawa-senyawa yang tertarik pada fraksi n-butanol tidak mampu menghambat biosintesis ergosterol. Dimana ergosterol merupakan suatu sterol utama membran sel jamur. Sehingga ketika dihambat akan mengganggu proses transport sehingga makromolekul dan ion-ion dalam sel hilang dan menyebabkan kehancuran yang irreversibel.

Aktivitas antijamur ekstrak daun ketepeng cina sangat baik karena pada konsentrasi rendah telah memberikan zona bunuh yang besar. Pada konsentrasi $5 \%$ terjadi aktivitas antijamur yang paling besar, merupakan konsentrasi efektif dari ekstrak metanol dan fraksi daun ketepeng cina yaitu konsentrasi yang memberikan aktivitas antijamur dengan zona bunuh terbesar karena dapat berdifusi dengan baik kedalam media agar. Pada konsentrasi $7 \%$ dan $9 \%$ aktivitas antijamur mengalami penurunan. Penurunan aktivitas antijamur ini disebabkan karena konsentrasi ekstrak yang cukup besar sehingga viskositas menjadi tinggi dan menyebabkan ekstrak tidak mampu berdifusi dengan baik ke dalam media agar, sehingga menunjukkan penurunan aktivitas antijamur. Dari gambar terlihat bahwa kontrol negatif menggunakan aquadest tidak menunjukkan adanya zona bunuh, sehingga dapat dipastikan bahwa zona bunuh yang terbentuk murni dari senyawa aktif yang terdapat pada ekstrak daun ketepeng cina.

Aktivitas antijamur paling besar ditunjukkan oleh ekstrak metanol. Hal ini kemungkinan disebabkan karena semua golongan senyawa tertarik oleh pelarut metanol. Sehingga aktivitas yang dihasilkan lebih besar dibandingkan fraksi n-heksana dan etil asetat.

\section{KESIMPULAN}

Ekstrak metanol, fraksi n-heksana dan fraksi etil asetat daun ketepeng cina memiliki aktivitas antijamur dalam membunuh pertumbuhan jamur M. furfur. 


\section{DAFTAR PUSTAKA}

[1]. Houghton PJ, Rahman A. 2010, Laboratory Handbook for Fractination of Natural Extracts. London.

[2]. Jawetz. EJ, Melnick L, Adelberg EA, 2001. Mikrobiologi Untuk Profesi Kesehatan. Terjemahan Huriati dan Hartanto. Penerbit Buku Kedokteran EGC, Jakarta

[3]. Priyanto. 2009. Farmakoterapi \& Terminologi Medis, Jakarta.

[4]. Setiabudy. R, Bahry B. 1995. Farmakologi dan Terapi (Antimikroba). UI-Press : Jakarta.
[5]. Somchit MN, Reezal I, Nur IE, Mutalib AR. 2002, In vitro antimicrobial activity of ethanol and water extracts of Cassia alata, Journal of Ethnopharmacology 84 (2003):14.

[6]. Phongpaicit S, Pujenjob N, Rukachaisirikul V, Ongsakul M. 2004, Antifungal activity from leaf extracts of Cassia alata L., Cassia fistula L. and Cassia tora L. Songklanakarin J. Sci. Technol., 2004, 26(5) : 741-748. 